\title{
Common Fluctuations in OECD Budget Balances
}

\author{
Christopher J. Neely and David E. Rapach
}

\begin{abstract}
The authors use a dynamic latent factor model to analyze comovements in OECD surpluses. The world factor underlying common fluctuations in budget surpluses across countries explains an average of 28 to 44 percent of the variation in individual country surpluses. The world factor, which can be interpreted as a global budget surplus index, declines substantially in the 1980s, rises throughout much of the 1990s, peaks in 2000, and declines again after the financial crisis of 2008. The authors then estimate similar world factors in national output gaps, dividend-to-price ratios, and military spending that significantly explain the variation in the world budget surplus factor. Idiosyncratic components of national budget surpluses correlate with well-known "unusual" country circumstances, such as the Swedish banking crisis of the early 1990s. (JEL C32, E62, F42, H62)
\end{abstract}

Federal Reserve Bank of St. Louis Review, Second Quarter 2015, 97(2), pp. 109-32.

\footnotetext{
Christopher J. Neely is an assistant vice president and economist at the Federal Reserve Bank of St. Louis. This project was undertaken while David E. Rapach, a professor in the department of economics at Saint Louis University, was a visiting scholar at the Federal Reserve Bank of St. Louis. The authors thank seminar participants at the Federal Reserve Bank of St. Louis, including Mike Owyang, Rody Manuelli, Howard Wall, and Steve Williamson, for very helpful comments. They also thank Dagfinn Rime and Nina Larsson Midthjell for helpful correspondence about Norway's economic and fiscal circumstances.

( ) 2015, The Federal Reserve Bank of St. Louis. The views expressed in this article are those of the author(s) and do not necessarily reflect the views of the Federal Reserve System, the Board of Governors, or the regional Federal Reserve Banks. Articles may be reprinted, reproduced, published, distributed, displayed, and transmitted in their entirety if copyright notice, author name(s), and full citation are included. Abstracts, synopses, and other derivative works may be made only with prior written permission of the Federal Reserve Bank of St. Louis.
} 


\section{Neely and Rapach}

comovements in fiscal balances illustrates the relevance of international influences in such matters.

We begin our analysis by estimating a dynamic factor model to identify the latent world factor underlying fiscal surpluses in 18 industrialized countries for 1980-2013. A latent factor model is a method to summarize common movements in related variables. For example, economists often use latent factor models to characterize the movement of interest rates on bonds of different maturities. ${ }^{1}$ The determinants or factors are called latent (hidden) because economists cannot directly observe them. But one can infer the behavior of these unobserved factors from the common movement across variables in the data. Factor analysis estimates these hidden factors to explain as much of the variance of the dependent variables as possible; this effectively condenses the information from many related variables into one or a few underlying influences. When the factors are allowed to be autocorrelated over time, then they are called "dynamic" factors. For interest rates, the first three factors can be readily interpreted as the level, slope, and curvature of the yield curve.

In this article, we use factor analysis to summarize and analyze the comovements of national fiscal balances and investigate the determinants of those balances. Why do we study such comovements? We start by observing that net lending is strongly positively correlated across countries. One might think that some international factor or factors drive this comovement, but their identity and quantitative importance are not clear. Potentially, international budget measures might be related for many reasons. For example, net lending tends to be correlated internationally because trade and capital flows link business conditions between countries. Asset market conditions, such as equity valuations and interest rates, are also linked internationally and can affect fiscal measures through capital gains tax revenues and interest payments on debt. Noneconomic factors, such as common trends in age demographics (e.g., the baby boom) or military expenditures (the peace dividend in the 1990s) can also affect fiscal balances.

A factor method captures covariation among many variables in a unified framework and has major advantages over alternative procedures for measuring comovements in national budget surpluses. For example, the performance of a few large countries will dominate a GDPweighted average of national surpluses. Similarly, pairwise correlations or related statistics are unwieldy, difficult to summarize, and fail to provide a unified framework. ${ }^{2}$

Our estimated world budget surplus factor explains a substantial portion of the variability in individual budget surpluses in member countries of the Organisation for Economic Co-operation and Development (OECD). Furthermore, the world factor, which can be interpreted as a global budget surplus index, varies markedly over our sample: It declines during the early 1980s and early 1990s, rises sharply for much of the 1990s, peaks in 2000 , and declines again after the financial crisis of 2008. Reassuringly, although our procedure does not weight countries by output, it still explains a substantial part of the variability in the U.S. surplus over the sample, which suggests that international factors are relevant even for a very large and relatively closed economy.

We then examine the relation between the world budget surplus factor and estimated world factors in national output gaps, equity valuation ratios, unexpected inflation, and military spending. These variables are potentially important determinants of national budget sur- 
pluses and can be viewed as nearly predetermined with respect to fiscal balances. Estimated world factors in national output gaps, price-to-dividend ratios, and military spending significantly explain fluctuations in the world budget surplus factor. Surprisingly, the world output gap factor even significantly explains the world factor in cyclically adjusted surplus measures, which indicates that OECD cyclical adjustments do not remove all business cycle variation in such measures. The fact that the world dividend-to-price ratio factor explains movements in the world budget surplus factor highlights the importance of swings in international equity markets in determining common trends in national budget balances. Finally, the significant relation between world military spending and world budget surplus factors points to the relevance of geopolitical events, such as the end of the Cold War.

In addition to discerning international trends in fiscal situations, the dynamic factor model decomposes national budget surpluses into common and idiosyncratic components. We interpret the common component as the impact of international conditions on a country's budget surplus. This allows one to evaluate whether the government's fiscal position is unusual compared with its historical record of budget comovement with similar countries. The common component thus provides a useful benchmark against which to gauge government policies and highlight the importance of particular national circumstances-for example, a war, tax changes, a domestic financial crisis, or atypical terms of trade as distinguished from common reactions to international economic conditions in determining fiscal balances and their sustainability. Substantial fluctuations in the idiosyncratic components of the national budget surpluses often readily relate to well-known "unusual" country circumstances. For example, a sharp decline in the idiosyncratic component of Sweden's budget surplus in the early 1990s clearly corresponds to the Swedish banking crisis.

While there is a vast literature on topics such as fiscal sustainability and the relation between deficits and growth, there is little work that characterizes international determinants of deficits in industrialized countries. ${ }^{3}$ Neely (2003) casually studies recent correlations among national budget deficits and speculates that common shocks to technology, demographics, commodity prices, and political uncertainty drive this covariance. Aside from Neely's (2003) very short study, two segments of the literature study the causes of deficits and therefore are tangentially related to the present issue of international influences on budget deficits. First, Roubini and Sachs's (1989) seminal empirical work, related to the theoretical study of Alesina and Tabellini (1990), presents evidence that OECD countries with short-tenure governments and coalition governments are more likely to experience deficits, although Edin and Ohlsson (1991) and de Haan and Sturm (1997) challenge the Roubini-Sachs findings. Second, Lane (2003) finds that OECD countries with volatile output and dispersed political power are more likely to exhibit procyclical fiscal policies; Strawczynski and Zeira (2009) determine that expenditures and deficits react countercyclically to transitory shocks, while government investment reacts procyclically to permanent shocks.

The remainder of the article is organized as follows. The next section outlines the dynamic factor model and its estimation. The third section describes the data and reports dynamic factor model estimation results for national budget surpluses, output gaps, equity valuation ratios, unexpected inflation, and military spending. The fourth section analyzes the relation- 


\section{Neely and Rapach}

ships between world factors in national budget surpluses and the other variables, and the fifth section examines idiosyncratic components in national budget surpluses.

\section{ECONOMETRIC METHODOLOGY}

The dynamic latent factor model is given by

$$
y_{i, t}=\beta_{i} f_{t}+\varepsilon_{i, t},
$$

where $y_{i, t}$ is the demeaned budget surplus as a share of GDP for country $i(i=1, \ldots, N)$ in year $t(t=1, \ldots, T) .{ }^{4}$ The world factor, $f_{t}$, is common across all of the $N=18$ OECD countries we consider and captures the global comovements in national budget surpluses. $\beta_{i}$ is a loading that measures the response of an individual country's budget surplus to fluctuations in the world factor. ${ }^{5}$ The final term in equation $(1), \varepsilon_{i, t}$, is an idiosyncratic component or countryspecific factor.

To make equation (1) a dynamic latent factor model, we permit $f_{t}$ and $\varepsilon_{i, t}$ to follow autoregressive (AR) processes. Each idiosyncratic component follows an $\operatorname{AR}(p)$ process, while the world factor obeys an $\operatorname{AR}(q)$ process:

$$
\varepsilon_{i, t}=\rho_{i, 1} \varepsilon_{i, t-1}+\ldots+\rho_{i, p} \varepsilon_{i, t-p}+u_{i, t},
$$

$$
f_{t}=\rho_{f, 1} f_{t-1}+\ldots+\rho_{f, q} f_{t-q}+u_{f, t},
$$

where $u_{i, t} \sim N\left(0, \sigma_{i}^{2}\right), u_{f, t} \sim N\left(0, \sigma_{f}^{2}\right)$, and $E\left(u_{i, t} u_{i, t-s}\right)=E\left(u_{f, t} u_{f, t-s}\right)=0$ for $s \neq 0$. We set $p=q=1$ when estimating the dynamic factor model in the next section; the results are not sensitive to other nonzero values for $p$ or $q$. We make the standard assumption that the shocks in equations (2) and (3), $u_{i, t}$ and $u_{f, t}$, respectively, are uncorrelated contemporaneously and at all leads and lags, implying that the world and country-specific factors are orthogonal.

Note that neither the signs nor scales of the world factor and factor loadings are separately identified in equation (1). For example, multiplying the world factor by -2 and the loadings by $-1 / 2$ produces exactly the same model. To normalize the signs of the factor and loadings, we restrict the loading on the world factor for Australia-the first country (alphabetically) in our sample-to be positive. To normalize the scales, we assume that $\sigma_{f}^{2}=1$ (e.g., see Sargent and Sims, 1977, and Stock and Watson, 1989, 1993). The sign and scale normalizations lack economic content and do not affect any economic inference. Nevertheless, the factor loadings in the next section are typically positive, which means that national budget surpluses are nearly all positively related to the world factor.

The dynamic factor model attributes comovements in national budget surpluses solely to the world factor, $f_{t}$, through the factor loadings, $\beta_{i}$. That is, $f_{t}$ tracks common fluctuations in national budget surpluses. To provide further intuition, consider two extremes. First, if $\sigma_{i}^{2}=0$ and $\beta_{i} \neq 0$ for all $i$, then $y_{i, t}=\beta_{i} f_{t}$ for all $i$, so that national budget surpluses are perfectly correlated. At the other extreme, if $\beta_{i}=0$ and $\sigma_{i}^{2} \neq 0$ for all $i$, then $y_{i, t}=\varepsilon_{i, t}$ for all $i$, so that national 
budget surpluses are completely uncorrelated. Of course, the patterns in the data are likely to fall between these extremes.

More formally, we can decompose the variation in a country's budget surplus into the share attributable to the world factor, $f_{t}$, and the country-specific factor, $\varepsilon_{i, t}$. Given that the factors are orthogonal, this variance decomposition is straightforward to compute for country $i$ :

$$
\begin{aligned}
& \theta_{i}^{\text {world }}=\beta_{i}^{2} \operatorname{var}\left(f_{t}\right) / \operatorname{var}\left(y_{i, t}\right), \\
& \theta_{i}^{\text {country }}=\operatorname{var}\left(\varepsilon_{i, t}\right) / \operatorname{var}\left(y_{i, t}\right),
\end{aligned}
$$

where

$$
\operatorname{var}\left(y_{i, t}\right)=\beta_{i}^{2} \operatorname{var}\left(f_{t}\right)+\operatorname{var}\left(\varepsilon_{i, t}\right)
$$

$\theta_{i}^{\text {world }}\left(\theta_{i}^{\text {country }}\right)$ is the proportion of the total variability in country $i$ 's budget surplus attributable to the world (country-specific) factor. As discussed earlier, the world factor will explain a larger proportion of the variation in countries with high $\beta_{i}$ and low $\operatorname{var}\left(\varepsilon_{i, t}\right)$ values. That is, these countries will have a higher $\theta_{i}^{\text {world }}$ (and lower $\theta_{i}^{\text {country }}$ ) value and thus will be more closely tied to global fluctuations in national budget surpluses.

Because the world factor is unobservable (latent), we cannot simply estimate it with conventional regression methods. Therefore, we follow Otrok and Whiteman (1998) and Kose, Otrok, and Whiteman $(2003,2008)$ in estimating the model with a Bayesian approach based on a Markov chain Monte Carlo (MCMC) algorithm to simulate draws from the relevant posterior distributions. We compute posterior distribution properties for the world factor and model parameters based on 10,000 MCMC replications after 2,000 burn-in replications. Otrok and Whiteman (1998) detail the estimation procedure. Because $\theta_{i}^{\text {world }}$ and $\theta_{i}^{\text {country }}$ are functions of the model parameters and data, we can generate these statistics for each MCMC replication, thereby building up their posterior distributions. ${ }^{6}$

We use the following diffuse conjugate priors, which are similar to those used in Otrok and Whiteman (1998) and Kose, Otrok, and Whiteman (2003, 2008), to implement Bayesian analysis:

$$
\begin{gathered}
\beta_{i} \sim N(0,1) \quad(i=1, \ldots, N), \\
\left(\rho_{i, 1}, \ldots, \rho_{i, p}\right)^{\prime} \sim N\left[0, \operatorname{diag}\left(1,0.5, \ldots, 0.5^{p-1}\right)\right] \quad(i=1, \ldots, N), \\
\left(\rho_{f, 1}, \ldots, \rho_{f, q}\right)^{\prime} \sim N\left[0, \operatorname{diag}\left(1,0.5, \ldots, 0.5^{q-1}\right)\right] \\
\sigma_{i}^{2} \sim \operatorname{IG}(6,0.001) \quad(i=1, \ldots, N),
\end{gathered}
$$




\section{Neely and Rapach}

where $I G$ denotes the inverse-gamma distribution. Equations (8) and (9) imply that the prior distributions for the AR parameters become more tightly centered on zero as the lag length increases. The prior for the idiosyncratic shock variances given by equation (10) is very diffuse; Otrok and Whiteman (1998) point out that only the first two moments exist for this proper prior. The results reported here are not sensitive to reasonable perturbations of these priors.

We also assume that the AR processes in equations (2) and (3) are stationary, which implies that national budget surpluses are also stationary. ${ }^{7}$ This sensible assumption is consistent with the fact that an intertemporal government budget constraint implies a mean-reverting budget deficit.

\section{DYNAMIC LATENT FACTOR MODEL ESTIMATION RESULTS}

\section{Data}

We consider four OECD measures of a country's fiscal position: (i) net lending as a share of GDP; (ii) primary balance as a share of GDP; (iii) cyclically adjusted net lending as a share of potential GDP; and (iv) cyclically adjusted primary balance as a share of potential GDP. Net lending is the most common measure of a country's fiscal situation-it is the general government budget surplus. ${ }^{8}$ The primary balance excludes interest payments from net lending. Cyclically adjusted net lending and primary balances are attempts by the OECD to measure the fiscal balance if the output gap were zero. ${ }^{9}$ We use annual data from all 18 OECD countries with full data samples for each of the four measures for the period 1980-2013.

We wish to explain the common variation in our budget surplus measures with other variables that can reasonably be viewed as predetermined with respect to the budget surplus. The output gap is an obvious candidate to explain cyclically unadjusted surpluses. Another candidate is the dividend-to-price ratio, a proxy for transitory but potentially persistent fluctuations in equity prices that provide temporary revenues through capital gains taxes. For example, the U.S. dividend yield and U.S. capital gains taxes as a share of GDP have a correlation of -0.62 from 1970 to 2008. Unexpected inflation can potentially affect debt financing. Finally, we consider whether trends in military spending might explain budget balances. Governments might treat defense spending variation as they typically treat wars-that is, as a temporary change in expenditures to be mostly accommodated by deficit financing rather than by suboptimally large discrete changes in taxation.

We use output gap and consumer price index (CPI) price-level data from the OECD and dividend-to-price ratio data from the Global Financial Data database. ${ }^{10}$ We measure unexpected inflation as the first difference in the CPI inflation rate (Atkeson and Ohanian, 2001). We obtain data on military spending from various issues of World Military Expenditures and Arms Transfers, which is compiled by the U.S. Department of State, Bureau of Arms Control, Verification and Compliance and obtained from the Inter-University Consortium for Political and Social Research. ${ }^{11}$ Military spending is measured as a percentage of GDP. 


\section{Summary Statistics}

Table 1 displays summary statistics for the fiscal surplus measures from 1980 to 2013. The average fiscal surplus (net lending) was -2.9 percent of GDP, and the average standard deviation was 3.6 percentage points. Extreme deficits or surpluses were fairly common: Eleven of the 18 countries had deficits exceeding 10 percent of GDP, while 5 had surpluses of at least 5 percent of GDP. Cyclically adjusted deficits were somewhat less variable than the unadjusted deficits, with a standard deviation of 3.0 percentage points. The average primary balances were near zero, indicating that government revenues nearly matched expenditures during this sample when one excludes interest payments on previously accumulated debt.

Figure 1 shows the time series of annual fiscal surpluses for the 18 OECD countries during the 1980-2013 sample. The (dashed) solid blue lines indicate (cyclically adjusted) net lending, while the (dashed) solid red lines indicate the (cyclically adjusted) primary balance. A few patterns are noteworthy. First, the values for red lines (primary balances) are generally more positive than those for the corresponding blue lines, reflecting the fact that almost all countries paid interest on existing debt during the sample. Second, the cyclically adjusted balances (dashed lines) do not appear substantially different from the unadjusted balances (solid lines), suggesting that the cyclical adjustments have had little effect. Norway is an exception to both these observations. Norway is unusual in that its primary balances are visibly lower than the full balances because the government receives significant revenues from asset holdings purchased by its sovereign wealth fund, which is funded by oil exports. In addition, the cyclical adjustment significantly changes Norway's fiscal balances because the OECD's cyclically adjusted net lending and GDP variables pertain to "mainland" net lending and GDP, which excludes oil production and shipping, rather than to total GDP and net lending. ${ }^{12}$

Figure 1 suggests that fiscal balances tend to move together internationally; for example, fiscal situations improve in the late 1990s across countries and deteriorate very substantially after the 2008 financial crisis. We use the dynamic factor model to formally measure the common component in national budget surpluses.

\section{Estimation Results for National Budget Surpluses}

For each budget surplus measure, Figure 2 shows the mean as well as the 0.10 and 0.90 quantiles of the posterior distribution for the country loadings on the world budget surplus factor. The estimated point loadings are always positive for all four measures, and the interior 80 percent of the posterior distribution generally excludes zero for almost all countries for all measures. ${ }^{13}$ Increases in the world factor thus imply rising budget surpluses for nearly every country. Japan's atypically low loadings are unsurprising in light of the particular macroeconomic challenges faced by Japan over much of the sample, including the "lost decade" of the 1990s. Norway has very low loadings for the cyclically adjusted balances, which indicates that non-business-cycle international influences have little effect on its fiscal balances. This lack of effect probably reflects Norway's position as an oil exporter, which cushions international influences on its economy and budget. ${ }^{14}$ Italy also tends to have low loadings for all four 


\section{Neely and Rapach}

\section{Table 1}

Summary Statistics for Annual Budget Surpluses: 18 OECD Countries (1980-2013)

\begin{tabular}{|c|c|c|c|c|c|c|c|c|}
\hline \multirow[b]{2}{*}{ Country } & \multicolumn{4}{|c|}{ Net lending as a share of GDP } & \multicolumn{4}{|c|}{$\begin{array}{l}\text { Cyclically adjusted net lending } \\
\text { as a share of potential GDP }\end{array}$} \\
\hline & Mean & SD & Minimum & Maximum & Mean & SD & Minimum & Maximum \\
\hline Australia & -0.015 & 0.025 & -0.051 & 0.024 & -0.013 & 0.023 & -0.050 & 0.023 \\
\hline Austria & -0.029 & 0.014 & -0.059 & -0.002 & -0.028 & 0.011 & -0.055 & -0.002 \\
\hline Belgium & -0.052 & 0.045 & -0.160 & 0.004 & -0.049 & 0.041 & -0.157 & 0.004 \\
\hline Canada & -0.033 & 0.037 & -0.090 & 0.029 & -0.033 & 0.032 & -0.088 & 0.014 \\
\hline Denmark & -0.011 & 0.038 & -0.110 & 0.050 & -0.009 & 0.028 & -0.090 & 0.040 \\
\hline Finland & 0.012 & 0.041 & -0.082 & 0.070 & 0.015 & 0.028 & -0.039 & 0.062 \\
\hline France & -0.035 & 0.016 & -0.075 & -0.003 & -0.035 & 0.014 & -0.069 & -0.008 \\
\hline Greece & -0.082 & 0.031 & -0.156 & -0.023 & -0.079 & 0.035 & -0.170 & -0.023 \\
\hline Iceland & -0.019 & 0.041 & -0.135 & 0.063 & -0.018 & 0.039 & -0.169 & 0.040 \\
\hline Ireland & -0.051 & 0.072 & -0.306 & 0.049 & -0.048 & 0.062 & -0.257 & 0.022 \\
\hline Italy & -0.067 & 0.039 & -0.123 & -0.009 & -0.065 & 0.038 & -0.121 & 0.003 \\
\hline Japan & -0.041 & 0.035 & -0.103 & 0.021 & -0.040 & 0.031 & -0.096 & 0.009 \\
\hline Netherlands & -0.031 & 0.024 & -0.092 & 0.020 & -0.029 & 0.022 & -0.082 & 0.007 \\
\hline Norway & 0.078 & 0.057 & -0.019 & 0.188 & -0.011 & 0.018 & -0.057 & 0.022 \\
\hline Spain & -0.047 & 0.036 & -0.111 & 0.024 & -0.043 & 0.028 & -0.108 & 0.007 \\
\hline Sweden & -0.013 & 0.040 & -0.112 & 0.036 & -0.011 & 0.029 & -0.073 & 0.028 \\
\hline United Kingdom & -0.036 & 0.033 & -0.112 & 0.058 & -0.034 & 0.028 & -0.100 & 0.055 \\
\hline United States & -0.051 & 0.030 & -0.128 & 0.008 & -0.046 & 0.025 & -0.110 & -0.003 \\
\hline Average & -0.029 & 0.036 & -0.112 & 0.034 & -0.032 & 0.030 & -0.105 & 0.017 \\
\hline
\end{tabular}

\begin{tabular}{|c|c|c|c|c|c|c|c|c|}
\hline \multirow[b]{2}{*}{ Country } & \multicolumn{4}{|c|}{ Primary balance as a share of GDP } & \multicolumn{4}{|c|}{$\begin{array}{l}\text { Cyclically adjusted primary balance } \\
\text { as a share of potential GDP }\end{array}$} \\
\hline & Mean & SD & Minimum & Maximum & Mean & SD & Minimum & Maximum \\
\hline Australia & 0.000 & 0.022 & -0.047 & 0.032 & 0.002 & 0.019 & -0.045 & 0.033 \\
\hline Austria & -0.004 & 0.013 & -0.025 & 0.025 & -0.003 & 0.011 & -0.022 & 0.019 \\
\hline Belgium & 0.017 & 0.037 & -0.088 & 0.064 & 0.020 & 0.035 & -0.085 & 0.066 \\
\hline Canada & -0.006 & 0.035 & -0.064 & 0.059 & -0.005 & 0.031 & -0.056 & 0.056 \\
\hline Denmark & 0.016 & 0.038 & -0.080 & 0.090 & 0.018 & 0.028 & -0.057 & 0.078 \\
\hline Finland & 0.009 & 0.040 & -0.087 & 0.079 & 0.012 & 0.028 & -0.043 & 0.072 \\
\hline France & -0.012 & 0.015 & -0.053 & 0.011 & -0.012 & 0.012 & -0.047 & 0.006 \\
\hline Greece & -0.023 & 0.035 & -0.107 & 0.038 & -0.020 & 0.039 & -0.120 & 0.043 \\
\hline Iceland & -0.003 & 0.038 & -0.135 & 0.067 & -0.003 & 0.039 & -0.169 & 0.044 \\
\hline Ireland & -0.012 & 0.069 & -0.280 & 0.067 & -0.010 & 0.064 & -0.233 & 0.072 \\
\hline Italy & 0.003 & 0.032 & -0.065 & 0.060 & 0.005 & 0.033 & -0.071 & 0.060 \\
\hline Japan & -0.031 & 0.037 & -0.091 & 0.032 & -0.029 & 0.034 & -0.084 & 0.026 \\
\hline Netherlands & 0.000 & 0.023 & -0.048 & 0.049 & 0.002 & 0.021 & -0.045 & 0.037 \\
\hline Norway & 0.059 & 0.057 & -0.048 & 0.161 & -0.030 & 0.020 & -0.086 & -0.007 \\
\hline Spain & -0.024 & 0.038 & -0.097 & 0.037 & -0.020 & 0.028 & -0.095 & 0.021 \\
\hline Sweden & 0.000 & 0.039 & -0.101 & 0.057 & 0.000 & 0.032 & -0.068 & 0.050 \\
\hline United Kingdom & -0.010 & 0.033 & -0.097 & 0.081 & -0.008 & 0.031 & -0.085 & 0.079 \\
\hline United States & -0.017 & 0.031 & -0.100 & 0.036 & -0.014 & 0.027 & -0.083 & 0.030 \\
\hline Average & -0.002 & 0.035 & -0.090 & 0.058 & -0.005 & 0.029 & -0.083 & 0.044 \\
\hline
\end{tabular}

NOTE: "Average" is the average across all countries. SD, standard deviation. 


\section{Figure 1}

Annual Budget Surpluses: 18 OECD Countries (1980-2013)
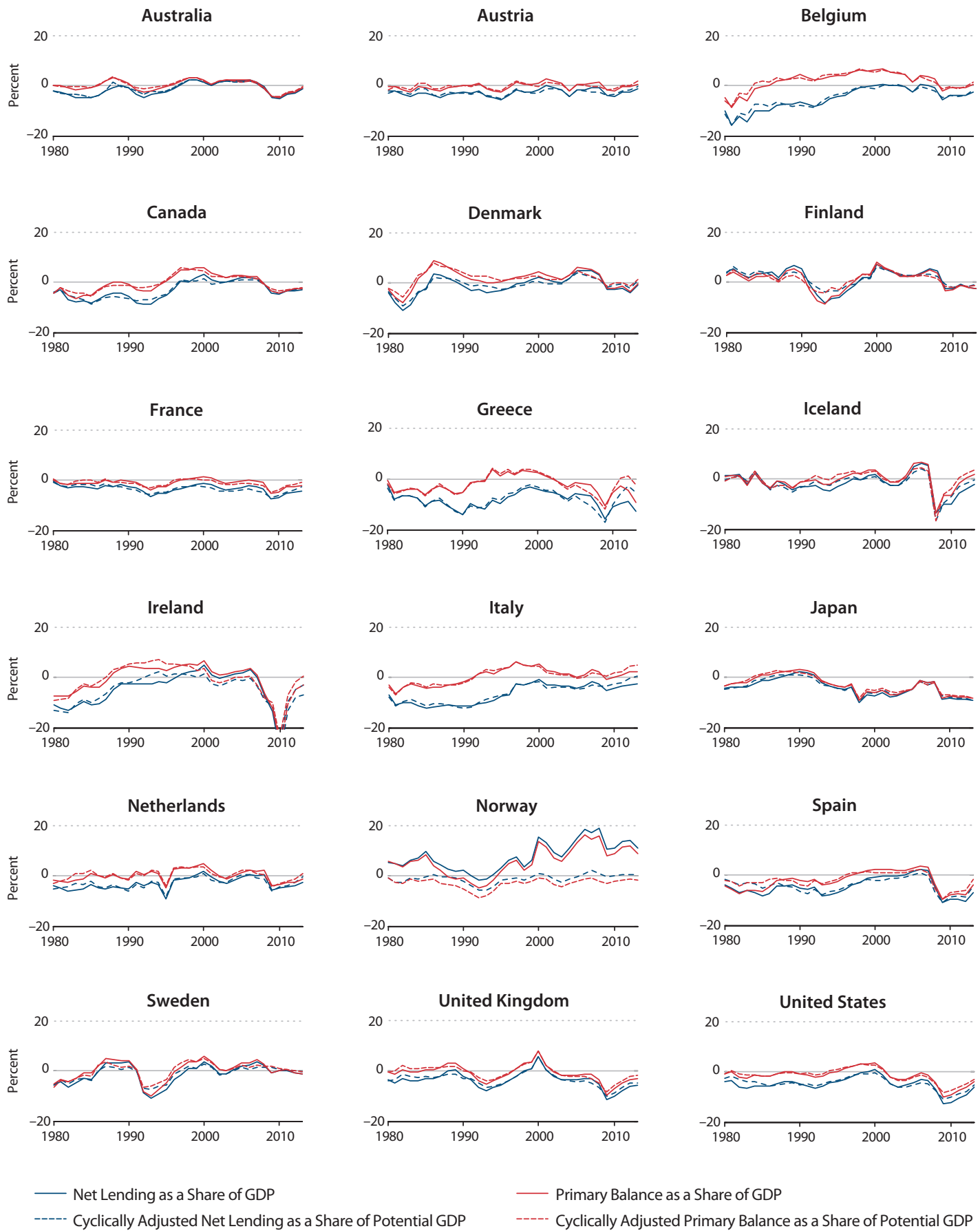


\section{Figure 2}

\section{Loadings on the World Factor for Budget Surpluses (1980-2013)}
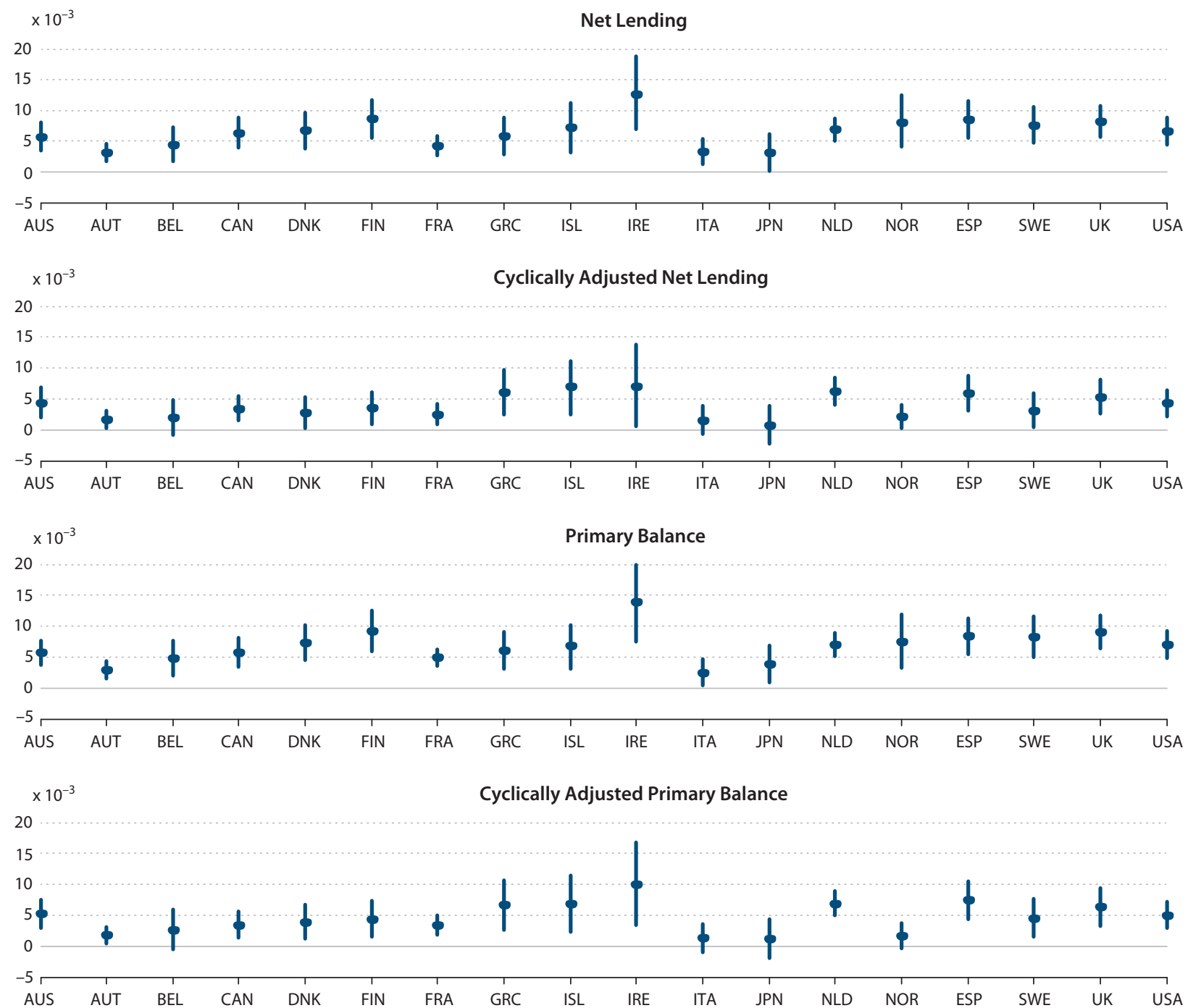

NOTE: The blue circles indicate the mean, and the vertical bars delineate the 0.10 and 0.90 quantiles for the posterior distribution of each country. AUS, Australia; AUT, Austria; BEL, Belgium; CAN, Canada; DNK, Denmark; FIN, Finland; FRA, France; GRC, Greece; ISL, Iceland; IRE, Ireland, ITA, Italy; JPN, Japan; NLD, the Netherlands; NOR, Norway; ESP, Spain; SWE, Sweden; UK, United Kingdom; USA, United States of America.

measures, which means that its high deficits over the sample period have only a very modest positive relation to the primary international factor that affects deficits in other countries.

Figure 3 displays the mean and the $0.10,0.33,0.66$, and 0.90 quantiles of the posterior distribution for the world factor in each of the four budget surplus measures. ${ }^{15}$ We note that removing interest payments from the budget balances makes little difference to the patterns in the world factors; compare the world factor for net lending with that for the primary balance. 


\section{Figure 3}

\section{World Factors for Budget Surpluses (1980-2013)}
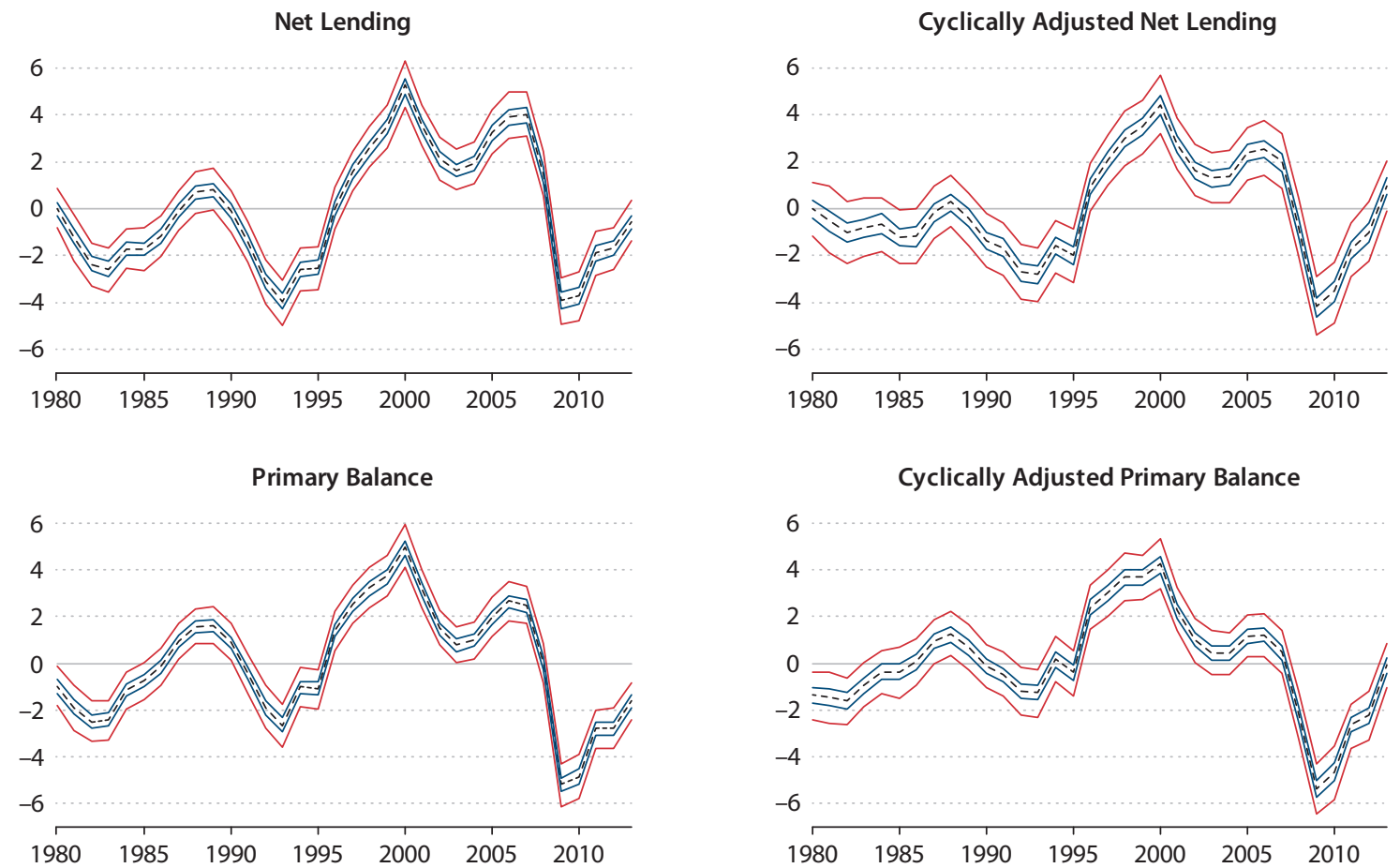

NOTE: The dashed black line delineates the mean of the posterior distribution. The blue (red) lines delineate the 0.33 and 0.66 (0.10 and 0.90$)$ quantiles for the posterior distribution.

Figure 3 illustrates significant fluctuations in the world factor for each of the fiscal measures: a fall in the early 1980s, a rise to a local maximum in 1989, another downturn to a trough in 1993, a subsequent rise leading to a global maximum in 2000, a relative plateau from 2000 to 2006 , and then a precipitous decline after the financial crisis of 2007-09. The 80 percent posterior coverage regions generally exclude zero. Overall, Figure 3 points to substantial common fluctuations in national budget surpluses.

Figure 4 illustrates $\theta_{i}^{\text {world }}$ variance decompositions, which measure the extent to which international influences affect national fiscal balances. As in Figure 2, the blue circles correspond to the mean of the posterior distribution for each country, while the vertical blue bars delineate the 0.10 and 0.90 quantiles. On average across the 18 countries, the point estimates indicate that the world factor explains 44 percent of total variance for net lending, 28 percent for cyclically adjusted net lending, 44 percent for the primary balance, and 35 percent for the cyclically adjusted primary balance. The variance decompositions are precisely measured. The difference between the cyclically adjusted and unadjusted measures suggests that the world business cycle explains at least part of the global influence on deficits. The variation in the 


\section{Figure 4}

$\theta_{i}^{\text {world }}$ Variance Decompositions for Budget Surpluses (1980-2013)

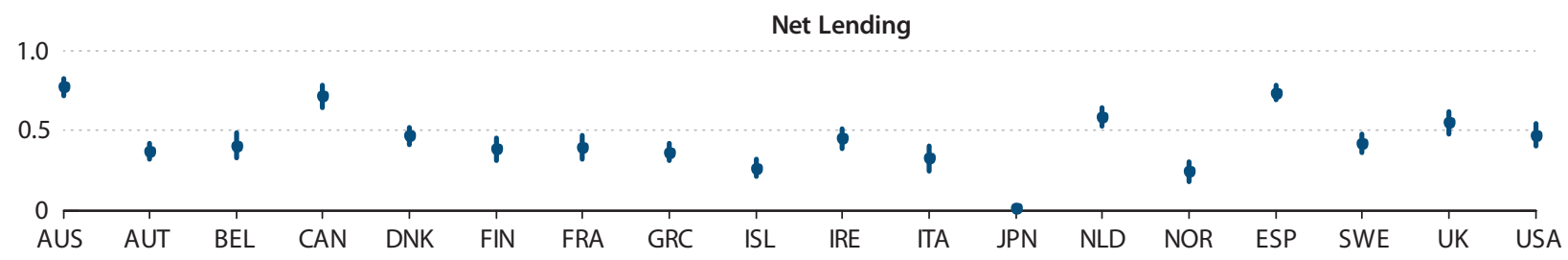

1.0

Cyclically Adjusted Net Lending
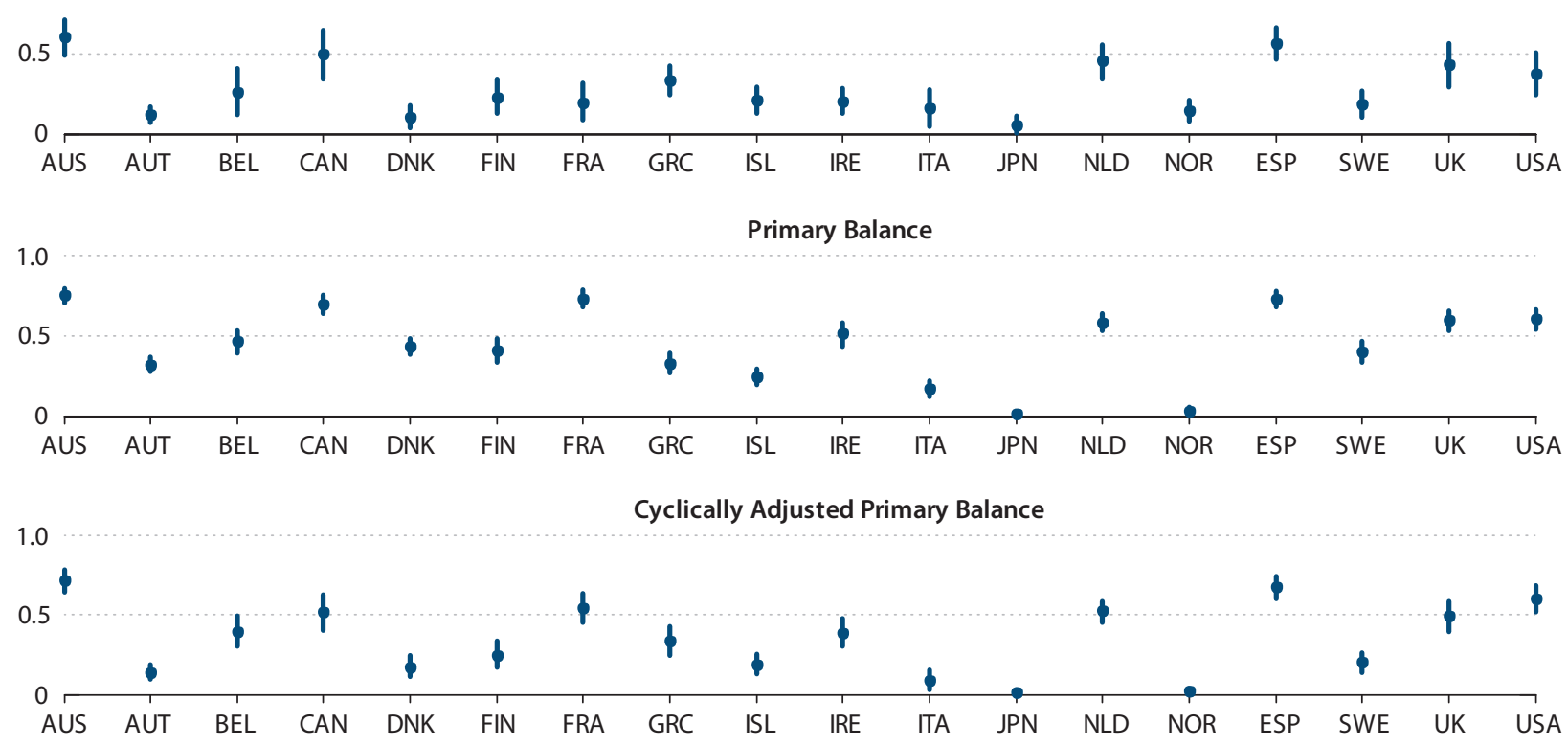

NOTE: The blue circles indicate the mean, and the vertical blue bars delineate the 0.10 and 0.90 quantiles for the posterior distribution of each country. See Figure 2 for definitions of country abbreviations.

cyclically adjusted measures indicates that there are other important global (non-businesscycle) influences or that the cyclical adjustment is inadequate. ${ }^{16}$ In sum, Figures 2 through 4 illustrate that common fluctuations in OECD national budget surpluses represent a significant portion of the variability in these surpluses. These common movements in cyclically adjusted and primary balances indicate that global influences on fiscal balances extend beyond business cycle and interest rate effects.

\section{Estimation Results for Predetermined Variables}

To explain the variation in the four measures of fiscal balances, we first compute world factors for national output gaps, dividend-to-price ratios, unexpected inflation, and military spending, which we treat as nearly predetermined driving variables. These variables are not 


\section{Figure 5}

Loadings on the World Factor for Predetermined Variables (1980-2013)
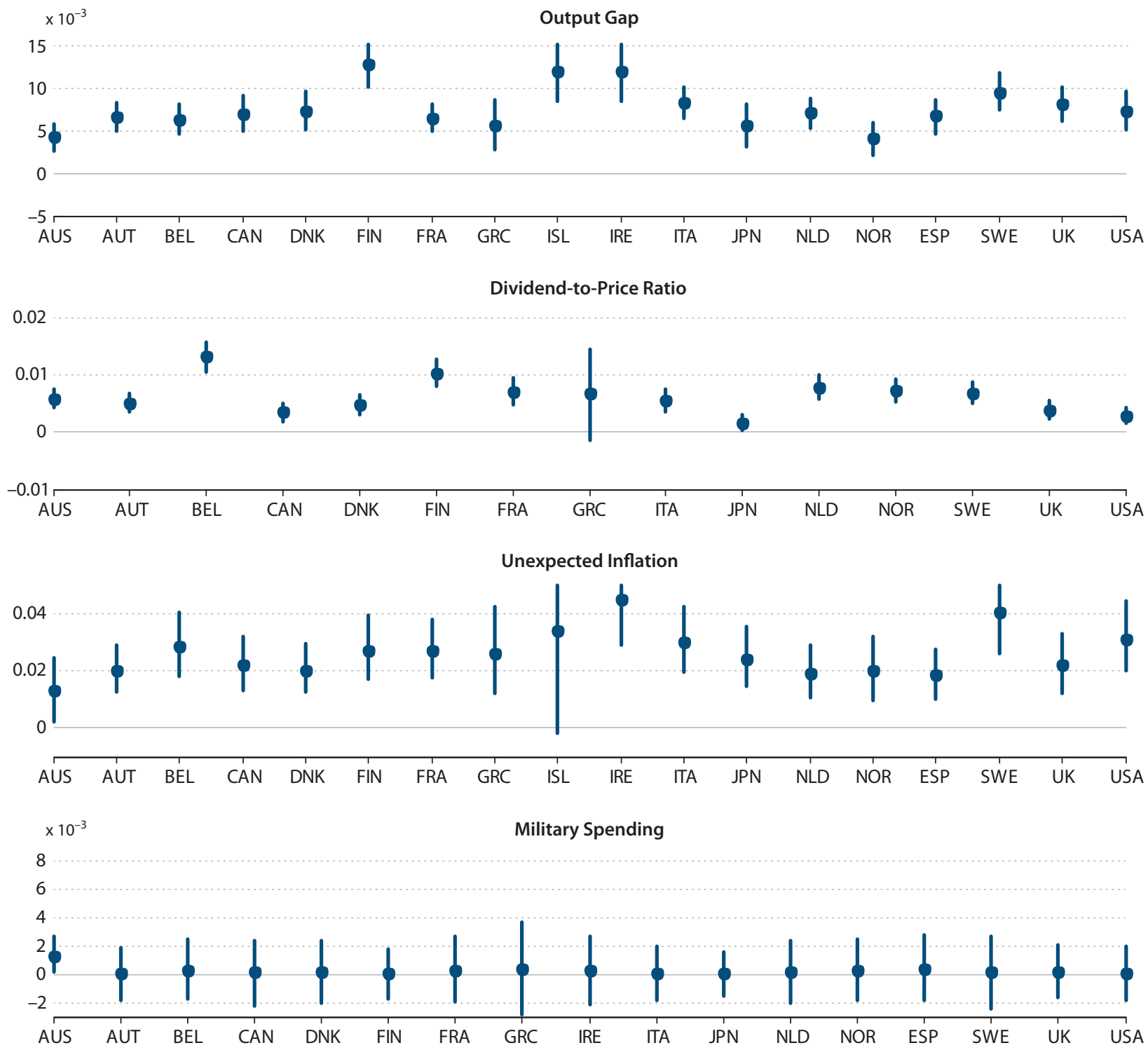

NOTE: The blue circles indicate the mean, and the vertical blue bars delineate the 0.10 and 0.90 quantiles for the posterior distribution of each country. See Figure 2 for definitions of country abbreviations. 


\section{Neely and Rapach}

\section{Figure 6}

World Factors for Predetermined Variables (1980-2013)
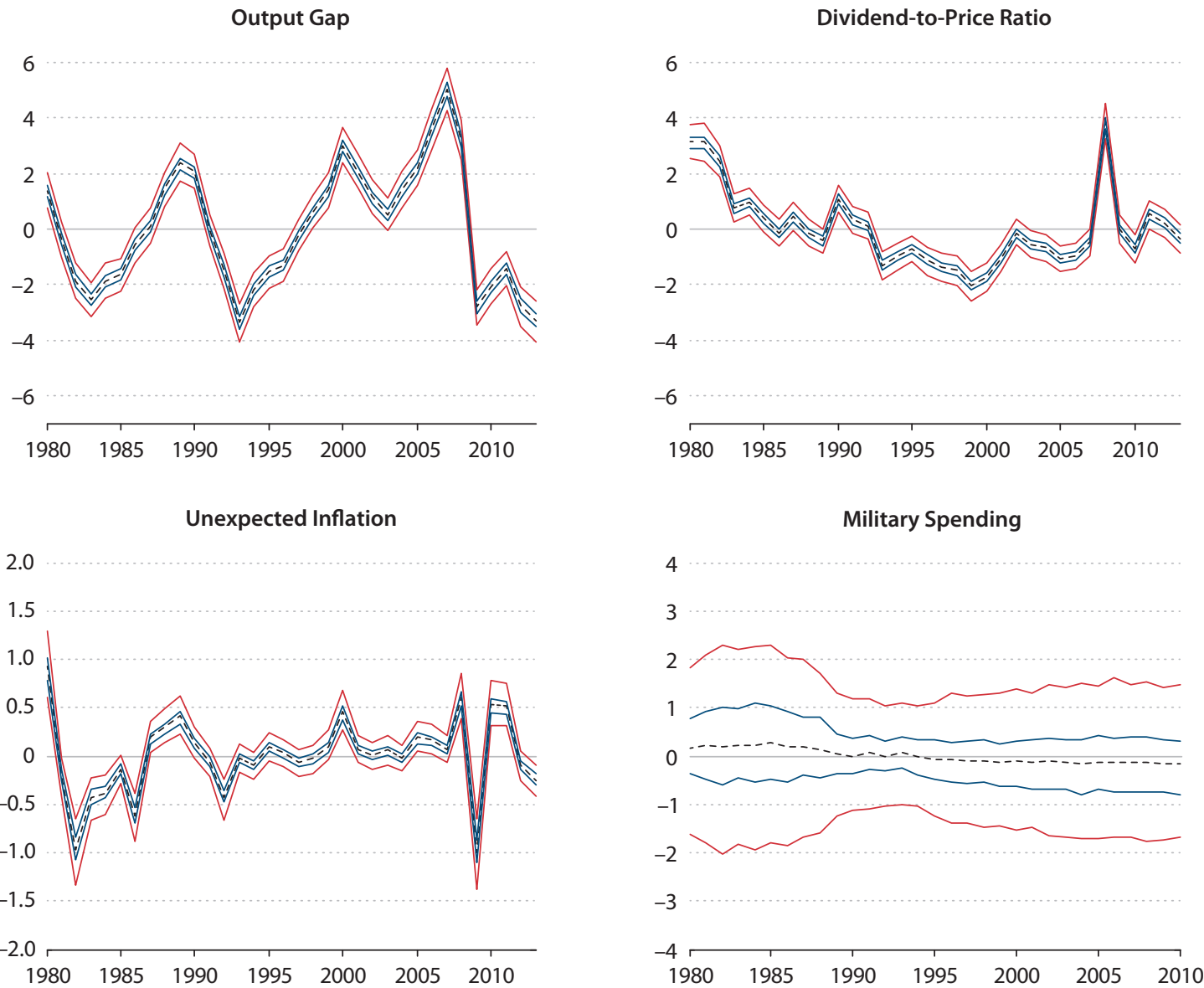

NOTE: The dashed black line delineates the mean of the posterior distribution. The blue (red) lines delineate the 0.33 and 0.66 ( 0.10 and 0.90$)$ quantiles for the posterior distribution. The world factor for military spending is estimated for 1980-2010.

truly exogenous, of course, but it seems reasonable to treat them as predetermined because we do not think the factor in global fiscal balances has a strong contemporaneous influence on them. To test the sensitivity of our results to this quasi-exogeneity assumption, we estimate instrumental variable regressions with lagged regressors as instruments and compare the results with those of ordinary least squares (OLS). The two sets of results are similar; this similarity supports the quasi-exogeneity assumption.

We compute the world factors in these variables in the same way that we computed the world factors for the fiscal balances. Figure 5 displays the mean and 0.10 and 0.90 quantiles for each country's loading on the world factor for each quasi-exogenous variable. The point estimates of the loadings indicate that each variable for each country is positively related to the world factor, with the exception of military spending for Japan. 
Figure 6 portrays the estimated world factor for each of the predetermined variables. The world factor for the output gap displays a temporal pattern similar to that in net lending and the primary balance. The 1990s bull market in global equities is clearly evident in the dividend yield world factor (high equity prices and thus low dividend-to-price ratios), as well as the 2008 plunge in prices. The world factor in unexpected inflation visibly covaries positively with the world output gap factor-the correlation between the series is 0.61 -which is in line with an expectations-augmented Phillips curve. World factors in output gaps, dividend-to-price ratios, unexpected inflation, and military spending fluctuate substantially from 1980 to 2013 and, with the exception of the military spending factor, are estimated reasonably precisely. ${ }^{17}$ The world factor in military spending is estimated very imprecisely, but there is a notable decrease in the early 1990s, shortly after the fall of the Berlin Wall. In the next section, we use the world factors for the four predetermined variables to explain the world fiscal surplus factors.

\section{RELATING PREDETERMINED VARIABLES TO BUDGET SURPLUSES}

A priori, we expect that the output gap significantly explains net lending and primary balances but does not explain the cyclically adjusted versions of those measures. We also conjecture that the dividend-to-price ratio is negatively related to all fiscal balances through capital gains taxes because, as stock prices exceed fundamental values, government revenues will rise above typical levels. Examination of U.S. capital gains tax receipt data (omitted for brevity) indicates that such receipts can vary by almost 1 percent of GDP within a few years. Unexpected inflation could influence fiscal deficits in either direction. On the one hand, if higher unexpected inflation signals an adverse aggregate supply shock, then one would expect it to reduce fiscal surpluses. Similarly, higher unexpected inflation could increase the cost of financing the short-term portion of the debt. On the other hand, if monetary stimulus produces unexpected inflation, one might expect a larger fiscal surplus. Finally, we expect that defense spending would be negatively related to all fiscal balances. That is, we expect that taxes would not always be immediately adjusted for changes in defense spending.

To explore the determinants of budget balances, we regress the world fiscal balance factors on world factors for the output gaps, dividend-to-price ratios, unexpected inflation, and military spending. We estimate both bivariate and multivariate regression models to contrast the results and highlight the dependencies in the explanatory variables. The bivariate regression model takes the following form:

$$
f_{t}^{\text {surplus }}=a+b_{j} f_{t}^{j}+e_{t}^{\text {surplus }}
$$

where $f_{t}^{\text {surplus }}$ is the world factor for the fiscal surplus in year $t$ and $f_{t}^{j}$ is the world factor for one of the four explanatory variables, indexed by $j$ : output gaps, dividend-to-price ratios, unexpected inflation, and military spending. The multivariate regression is as follows:

$$
f_{t}^{\text {surplus }}=a+\sum_{j=1}^{4} b_{j} f_{t}^{j}+e_{t}^{\text {surplus }} .
$$




\section{Neely and Rapach}

We estimate equations (11) and (12) using OLS, accounting for autocorrelation with NeweyWest (1987) standard errors.

We present the regression results with two caveats. First, the factors on both the left-and right-hand sides of the regressions are generated variables. The error in the left-hand-side variables (i.e., the world budget surplus factors) will decrease the apparent amount of predictability in the relations. The estimated $R$-squared value will then understate the $R$-squared value that is theoretically expected in the absence of measurement error because the estimated total sum of squares will exceed the total sum of squares without measurement error. Likewise, the error in the predetermined variables on the right-hand side will attenuate their estimated coefficients toward zero and thus inflate their $p$-values. Therefore, the error in the factor estimation will cause our regressions to present a conservative picture of the relation between the fiscal surpluses and predetermined variables.

Second, we view the right-hand-side variables in equations (11) and (12) as nearly predetermined. Strictly speaking, these variables are endogenous, which means the coefficients will be subject to simultaneity bias. We believe the explanatory variables are largely predetermined, however, and unlikely to exhibit strong contemporaneous reactions to fiscal balances. Therefore, we do not believe that simultaneity bias will strongly influence our results. ${ }^{18}$

Table 2 presents the bivariate and multiple regression results for all four fiscal surplus measures. The sample period is 1980-2013, except for regressions including military spending, for which the sample period is 1980-2010. Given that including military spending reduces the sample length, is imprecisely estimated, and is very persistent, we estimate multiple regression models both with and without this variable.

In the bivariate regressions, the output gap factor is positive and significant at the 1 percent level for all four fiscal measures, presumably through the familiar taxing and spending channels. International business cycle fluctuations have the most explanatory power for the unadjusted surpluses: net lending and the primary balance, with $R$-squared statistics of 73 percent and 59 percent, respectively. This is not surprising, as cyclical adjustment would be expected to remove some or all international influences. The explanatory power of the output gap factor for the cyclically adjusted surpluses is surprisingly large, however, with very sizable $R$-squared statistics of 41 percent and 24 percent for the cyclically adjusted net lending and cyclically adjusted primary balance, respectively. The OECD's cyclical adjustments apparently do not completely capture international business cycle effects on budgets.

Consistent with the idea that higher equity prices increase capital gains tax revenues, the dividend-to-price ratio factor is significantly negatively related to cyclically adjusted net lending, the primary balance, and cyclically adjusted primary balance factors in the bivariate regressions. The $R$-squared statistics are sizable: 15 percent, 18 percent, and 28 percent for cyclically adjusted net lending, the primary balance, and cyclically adjusted primary balance, respectively. Our results indicate that global bull (bear) equity markets significantly raise (lower) the primary balance in industrialized countries. The dividend-to-price ratio factor is not significantly related to the net lending factor, although the relationship is nearly significant at the 10 percent level. The dividend-to-price factor explains more of the variability in the primary balances than in the non-primary surpluses. A systematic relationship between global equity valuations and interest rates could create this difference. 


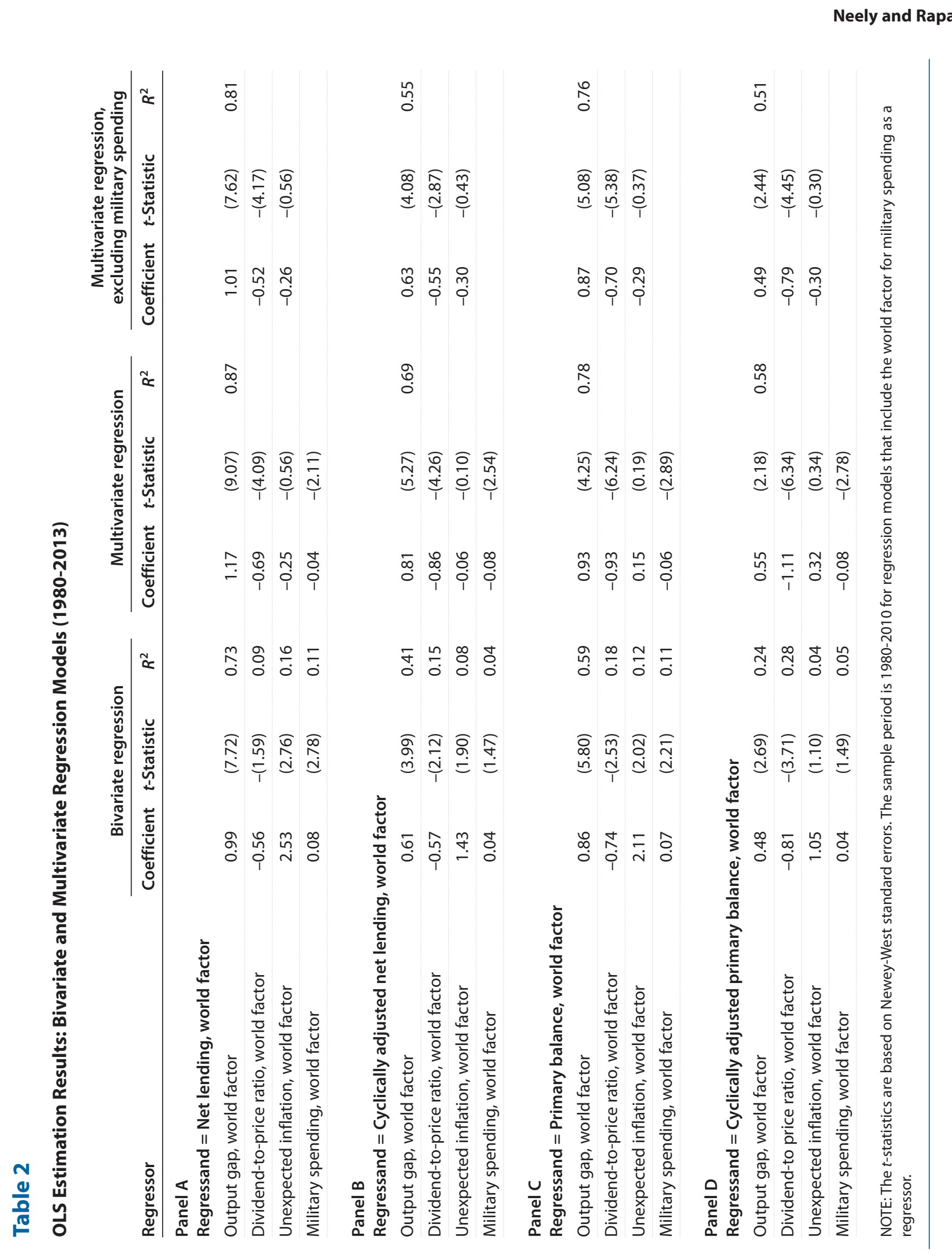


The unexpected inflation factor significantly explains net lending, cyclically adjusted net lending, and the primary balance in the bivariate regressions. The $R$-squared values are modest, ranging from 8 to 16 percent. As noted in the section "Estimation Results for Predetermined Variables," the unexpected inflation factor is positively correlated with the output gap factor, so the significantly positive coefficients on the unexpected inflation factor likely capture similar business cycle effects.

The military spending factor is significant at the 1 percent level in the bivariate regression model for net lending and the primary balance but not the cyclically adjusted measures. The $R$-squared statistics are modest: 11 percent for both the net lending and primary balance measures. The estimated positive coefficients are counterintuitive; they likely reflect longterm upward trends in deficits as military spending as a percentage of GDP declines. Thus, they are a spurious product of a regression with a very persistent variable.

In the multiple regressions, the output gap, the dividend-to-price ratio, and the military spending factors are significant at conventional levels for all four measures. The significance of the output gap factor confirms that the cyclical adjustments do not completely capture international business cycle effects. Unexpected inflation coefficients are no longer significant in any of the multiple regressions, probably because the unexpected inflation factor is strongly correlated with the output gap factor. The military spending factor significantly explains all of the fiscal surplus factors at conventional levels. Importantly, the signs of the coefficient on the military spending factor become reliably and significantly negative, as one would expect, when the other variables are controlled for. The $R$-squared statistics in the sixth column of Table 2 show that world factors in the four predetermined variables collectively explain most of the variability in the global budget surplus factors, especially for net lending and the primary balance, where the $R$-squared statistics are 87 percent and 78 percent, respectively.

The imprecise estimation and strong persistence in the military spending variable are causes for concern. Therefore, we also estimate the multiple regression without the military variable and use a 1980-2013 sample. In this specification, the output gap and dividend-toprice ratio factors remain significant at the 1 percent level for each of the four surplus factors. The unexpected inflation factor remains insignificant at conventional levels in each of the four regressions. The $R$-squared statistics continue to be substantial in the final column of Table 2, ranging from 51 to 81 percent.

In summary, Table 2 indicates that the output gap, the price-to-divided ratio, and the military spending world factors substantially determine fluctuations in fiscal surplus world factors. Unexpected inflation also has predictive value when considered by itself but not in conjunction with the other variables. Global expansions, bullish equity markets, and reduced military spending improve fiscal balances across industrialized countries. ${ }^{19}$

\section{IDIOSYNCRATIC COMPONENTS}

Our method of investigating international influences on fiscal balances permits us to isolate the effect of domestic events on fiscal balances. That is, we can examine the common and idiosyncratic components of budget surpluses to determine the effect of domestic events or 


\section{Figure 7}

\section{Common and Idiosyncratic Components for Demeaned Net Lending: Selected Countries (1980-2013)}
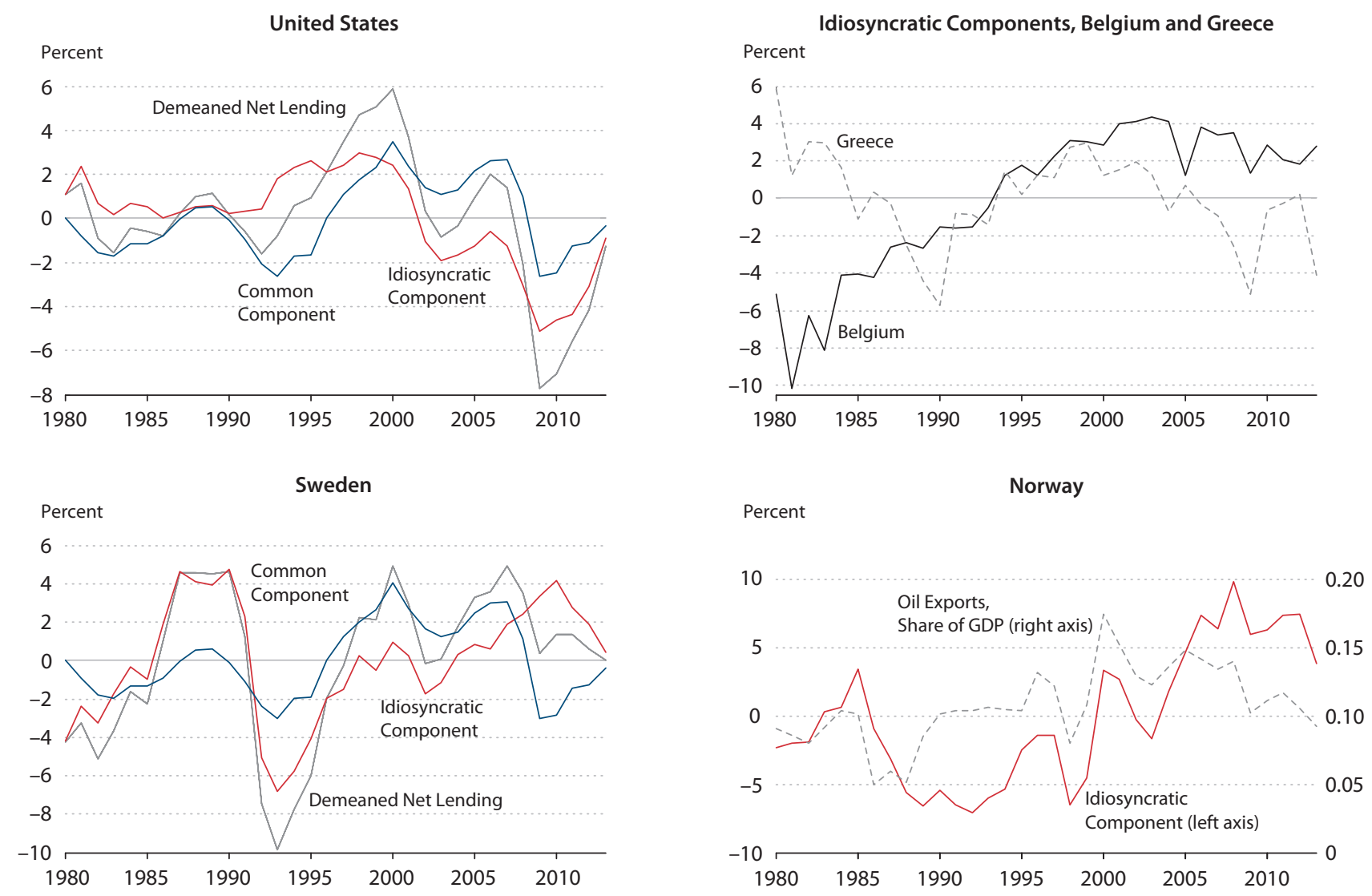

policies. Figure 7 displays common and idiosyncratic components for net lending of selected countries. ${ }^{20}$

The top-left panel of Figure 7 shows demeaned U.S. net lending and its two components: the common component (the product of the world factor and its loading) and the U.S. idiosyncratic component. Demeaned net lending is the sum of the common and idiosyncratic components, of course. Note that because net lending is demeaned and the sample mean for U.S. net lending was -5.1 percent, values of demeaned net lending near zero still indicate fairly high deficits. The figure illustrates that both global and idiosyncratic components contributed to all the major movements in U.S. net lending. For example, both components contributed to the increase in deficits - that is, the decrease in net lending-in the early 1980s and the movement from substantial deficits to surpluses in the 1990s. The substantial deterioration in the U.S. fiscal balance in 2001 partly reflected the common component but was mostly due to the U.S. idiosyncratic component, however. That is, U.S. factors-such as the 2001 tax cuts, the September 11th attacks, and the wars in Afghanistan and Iraq-bore the lion's share of the 


\section{Neely and Rapach}

blame for the decline in the fiscal situation during that period. The fastest changes in U.S. net lending occurred during the 2008 financial crisis, however-which, again, were driven by large declines in both the common and idiosyncratic components.

The upper-right panel of Figure 7 portrays the idiosyncratic components for a pair of highly indebted European countries, Belgium and Greece. The idiosyncratic components were quite different in these two countries during the 1980s. Both countries, however, faced pressure in the 1990s to reduce their debt and deficits to levels required by the Treaty on European Union (informally, the Maastricht treaty) for entry into the European Economic and Monetary Union on January 1, 1999. This regional influence is clearly evident during the rise in the idiosyncratic components for these countries during the 1990s.

The lower-left panel of Figure 7 shows the common and idiosyncratic components for Sweden and highlights the important fiscal effect of the Swedish banking crisis of 1990-94. During the late 1980s, the idiosyncratic component contributed to a marked improvement in Sweden's fiscal surplus. With the advent of the banking crisis in 1990, however, Sweden was forced to spend relatively large sums to recapitalize its banking systems, which resulted in a sharp decrease in the idiosyncratic component of net lending during the early 1990s. The common component also decreased in the early 1990s; thus, the early 1990s were characterized by a steep decline in overall Swedish net lending. As one might expect, the resolution of the banking crisis led to a sizable increase in the idiosyncratic component during the late 1990s.

Finally, the lower-right panel of Figure 7 illustrates the importance of the oil market for Norway. In addition to the Norwegian idiosyncratic component, the figure shows the value of Norwegian oil exports as a share of GDP. The two variables generally move together, indicating that oil revenues are especially important for improving the fiscal situation in Norway. Observe, however, that oil revenues increased while the idiosyncratic component decreased around 1990. This likely reflects the influence of the Scandinavian banking crisis that affected Norway and started earlier than the Swedish crisis (Vale, 2004). The increase in Norway's oil revenues during this time helped to cushion the negative budgetary impulse of the banking crisis.

In summary, decomposing net lending into common and idiosyncratic components allows us to more easily evaluate the effects of domestic events and policies on a country's fiscal situation.

\section{CONCLUSION}

The emergence of the prospect of unprecedented deficits in the United States has rekindled interest in the causes of such imbalances and the question of responsibility for them. Properly addressing these imbalances requires understanding their sources and influences, including international influences.

While researchers, such as Roubini and Sachs (1989), have examined how political polarization might affect deficits, and others, such as Lane (2003), have evaluated the cyclicality of deficits, there has been no significant previous work on internationally driven comovements in deficits. In this article, we use a dynamic latent factor model to identify substantial international comovements in four budget surplus measures for 18 OECD countries for 1980-2013 
with a dynamic latent factor model. Depending on the measure of the fiscal surplus, the world factor explains 28 to 44 percent of surplus variability, on average, across countries. The world factor explains 47 percent of the variation in U.S. net lending, for example.

World factors in national output gaps, dividend-to-price ratios, and military spending usually significantly explain variation in the four world fiscal surplus factors. Surprisingly, the output gap factor significantly explains not only the net lending and primary balance factors, but also the cyclically adjusted versions of those measures. This indicates that the OECD cyclical adjustments do not completely remove the contribution of the international business cycle on fiscal balances. The importance of the world dividend-to-price ratio factor highlights the role of global equity market conditions in affecting fiscal balances, while the significance of the military spending factor points to the effect of an international peace dividend in the 1990s.

Our results show that trends in international business cycles, equity markets, and military spending create common fluctuations in national budget surpluses. The discovery of a significant global factor in international budget deficits suggests avenues for future research. What global political economy incentives influence fiscal balances? Do individual governments respond optimally to these international shocks? Can individual country characteristics explain varying sensitivities of national fiscal balances to international influences? Our findings highlight the relevance of such questions. 


\section{Neely and Rapach}

\section{NOTES}

1 Factor analysis has been used to model covariation in many types of related variables. For example, individuals who are good at certain mental or physical tasks are very often good at other types of mental or physical tasks that are not directly related. That is, students who get an A in economics are likely to have above-average grades in other courses. Charles Spearman, a psychologist, developed factor analysis to describe the tendency of children's performance on cognitive tasks to be positively correlated.

2 Researchers have recently employed dynamic latent factor models to measure global fluctuations in national real output growth and inflation rates; see, for example, Kose, Otrok, and Whiteman $(2003,2008)$ with respect to real output growth and Ciccarelli and Mojon (2010), Monacelli and Sala (2009), and Neely and Rapach (2011) with respect to inflation.

3 For example, Corsetti and Roubini (1991), Chalk and Hemming (2000), and Heller (2005) consider tests of fiscal sustainability, while Dornbusch and Reynoso (1989), Kneller, Bleaney, and Gemmell (1999), Adam and Bevan (2005), and Heller (2005) analyze the relation between deficits and growth.

4 In the dynamic latent factor models discussed in the next section, $y_{i, t}$ can also represent the demeaned national output gap, dividend-to-price ratio, unexpected inflation rate, or military spending as a share of GDP.

5 The comovement in net-lending-to-GDP ratios is driven almost entirely by comovement in net lending rather than by comovement in GDP. International net lending correlations are, on average, very similar if one uses the predicted value of GDP from a log linear trend as the denominator in the net lending ratio rather than GDP itself. Iceland and Japan show the most evidence of correlation through GDP rather than net lending.

6 The latent world factor could also be estimated using principal components (Stock and Watson, 2002, and Bai, 2003), with inferences based on the asymptotic distribution theory in Bai (2003). Principal component estimates of the world factors are similar to the Bayesian estimates. The Bayesian approach, however, is likely to provide more accurate finite-sample results as the asymptotic theory in Bai (2003) is based on $N \rightarrow \infty$ and $T \rightarrow \infty$.

7 We enforce the stationarity restrictions by discarding draws of the AR parameters that do not satisfy the restrictions. We do the same to enforce the sign restriction on the factor loading for Australia. Inadmissible AR parameters and Australian loadings are rarely drawn, especially after the burn-in replications.

8 The OECD defines "general government accounts" as follows: "General government accounts are consolidated central, state and local government accounts, social security funds and non-market non-profit institutions controlled and mainly financed by government units" (see http://stats.oecd.org/glossary/detail.asp?ID=1095).

9 The OECD denotes the four measures as "central government net lending - as a percentage of GDP," "government primary balance - as a percentage of GDP," "cyclically adjusted government net lending —as a percentage of potential GDP," and "cyclically adjusted government primary balance-as a percentage of potential GDP."The OECD describes its cyclical adjustment method at http://www.oecd.org/dataoecd/0/61/36336878.pdf.

${ }^{10}$ The OECD denotes these variables as "Output gap of the total economy" and "Consumer Price Index." Full-sample dividend-to-price ratio data are unavailable for Iceland, Ireland, and Spain, and we exclude these countries when estimating the dividend-to-price ratio world factor in the section "Estimation Results for Predetermined Variables."

${ }^{11}$ The current issue of World Military Expenditures and Arms Transfers is available at http://www.state.gov/t/avc/rls/rpt/wmeat/2014/index.htm. Back issues were downloaded from https://www.icpsr.umich.edu/icpsrweb/ICPSR/series/61. Military spending data are available through 2005. Data are unavailable for Iceland, and we exclude Iceland when we estimate the military spending world factor in the section "Estimation Results for Predetermined Variables."

12 The Norwegian government owns all petroleum resources on the Norwegian continental shelf. Taxes and license fees from the petroleum sector go to the Government Pension Fund of Norway, which uses them both for longterm investment and directly for government expenditures. Oil profits are taxed at very high rates, and revenues from those taxes reached $\$ 36$ billion in 2011, or almost 8.6 percent of Norwegian GDP (Hsieh, 2013). See http://www.oecd.org/norway/47473811.pdf for the OECD's definition of mainland GDP.

${ }^{13}$ We use the mean of the posterior distribution as the point estimate.

${ }^{14}$ The United Kingdom was also an oil exporter for most of the sample, but its oil exports were smaller in absolute value and much less important compared with the size of its economy and government budget. 
15 Observe that the world budget surplus factor is an index, so a world surplus factor of zero in Figure 3 does not necessarily represent a balanced budget.

${ }^{16}$ As expected, the $\beta_{i}$ and $\theta_{i}^{\text {world }}$ estimates are positively correlated across countries, with correlation coefficients of $0.30,0.53,0.26$, and 0.53 for net lending, cyclically adjusted net lending, primary surplus, and cyclically adjusted primary surplus, respectively.

17 The world factors typically explain a substantial portion of the variability in national output gaps, price-to-divided ratios, unexpected inflation, and military spending, with averages across countries of $0.55,0.57,0.42$, and 0.35 , respectively. For brevity, we do not report the complete results for the variance decompositions; these are available upon request from the authors.

${ }^{18}$ Our exercise is similar in spirit to the work of Crucini, Kose, and Otrok (2011) in the context of explaining the G-7 business cycle. They first estimate a world factor in G-7 real output growth rates, which they then explain using world factors in G-7 measures of productivity, fiscal policy, monetary policy, oil prices, and terms of trade.

${ }^{19}$ We also estimated fixed-effects panel regression models with national fiscal surpluses serving as regressands and national output gaps, price-to-dividend ratios, unexpected inflation, and military spending serving as regressors. (For brevity, we do not report complete results but they are available upon request from the authors.) The national output gap and military spending are significant determinants of national net lending and cyclically adjusted net lending, while the national output gap, the dividend-to-price ratio, and military spending are significantly related to the national primary balance and cyclically adjusted primary balance. Of course, panel estimation does not explicitly identify world factors in national budget surpluses and their determinants - the focus of our articlebut it does appear to pick up aspects of the links documented in Table 2.

${ }^{20}$ The complete set of common and idiosyncratic components is available upon request from the authors.

\section{REFERENCES}

Adam, Christopher S. and Bevan, Daniel L. "Fiscal Deficits and Growth in Developing Countries." Journal of Public Economics, April 2005, 89(4), pp. 571-97.

Alesina, Alberto and Tabellini, Guido. "A Positive Theory of Fiscal Deficits and Government Debt." Review of Economic Studies, July 1990, 57(3), pp. 403-14.

Atkeson, Andrew and Ohanian, Lee E. "Are Phillips Curves Useful for Forecasting Inflation?" Federal Reserve Bank of Minneapolis Quarterly Review, Winter 2001, 25(1), pp. 2-11; https://www.minneapolisfed.org/research/qr/qr2511.pdf.

Bai, Jushan. "Inferential Theory for Factor Models of Large Dimensions." Econometrica, 2003, 71(1), pp. 135-71.

Calmes, Jackie. "Obama Plans Major Shifts in Spending." New York Times, February 26, 2009; http://www.nytimes.com/2009/02/27/us/politics/27web-budget.html.

Chalk, Nigel and Hemming, Richard. "Assessing Fiscal Sustainability in Theory and Practice." IMF Working Paper No. WP/00/81, International Monetary Fund, April 2000; http://www.imf.org/external/pubs/ft/wp/2000/wp0081.pdf.

Ciccarelli, Matteo and Mojon, Benoit. "Global Inflation." Review of Economics and Statistics, August 2010, 92(3), pp. 524-35.

Corsetti, Giancarlo and Roubini, Nouriel. “Fiscal Deficits, Public Debt and Government Solvency: Evidence from OECD Countries." NBER Working Paper No. W3658, National Bureau of Economic Research, March 1991; http://www.nber.org/papers/w3658.pdf.

Crucini, Mario J.; Kose, M. Ayhan and Otrok, Christopher. "What Are the Driving Forces of International Business Cycles?" Review of Economic Dynamics, Special Issue January 2011, 14(1), pp. 156-75.

de Haan, Jakob and Sturm, Jan-Egbert. "Political and Economic Determinants of OECD Budget Deficits and Government Expenditures: A Reinvestigation." European Journal of Political Economy, December 1997, 13(4), pp. 739-50.

Dornbusch, Rudiger and Reynoso, Alejandro. "Financial Factors in Economic Development." American Economic Review, May 1989, 79(2), pp. 204-09.

Edin, Per-Anders and Ohlsson, Henry. "Political Determinants of Budget Deficits: Coalition Effects versus Minority Effects." European Economic Review, December 1991, 35(8), pp. 1597-603. 


\section{Neely and Rapach}

Heller, Peter S. “Understanding Fiscal Space." IMF Policy Discussion Paper No. PDP/05/4, International Monetary Fund, March 2005; http://www.imf.org/external/pubs/ft/pdp/2005/pdp04.pdf.

Hsieh, Esther. "What Norway Did with Its Oil and We Didn't." Globe and Mail, May 16, 2013; http://www.theglobeandmail.com/report-on-business/economy/canada-competes/what-norway-did-with-itsoil-and-we-didnt/article11959362/.

Kneller, Richard; Bleaney, Michael F. and Gemmell, Norman. “Fiscal Policy and Growth: Evidence from OECD Countries." Journal of Public Economics, November 1999, 74(2), pp. 171-90.

Kose, M. Ayhan; Otrok, Christopher and Whiteman, Charles H. "International Business Cycles: World, Region, and Country-Specific Factors." American Economic Review, September 2003, 93(4), pp. 1216-39.

Kose, M. Ayhan; Otrok, Christopher and Whiteman, Charles H. “Understanding the Evolution of World Business Cycles." Journal of International Economics, May 2008, 75(1), pp. 110-30.

Lane, Philip R. "The Cyclical Behaviour of Fiscal Policy: Evidence from the OECD.” Journal of Public Economics, December 2003, 87(12), pp. 2661-75.

Leonhardt, David. "America's Sea of Red Ink Was Years in the Making." New York Times, June 9, 2009; http://www.nytimes.com/2009/06/10/business/economy/10leonhardt.html.

Monacelli, Tommaso and Sala, Luca. "The International Dimension of Inflation: Evidence from Disaggregated Consumer Price Data." Journal of Money, Credit, and Banking, 2009, 41(Suppl. s1), pp. 101-20.

Neely, Christopher J. "Global Factors in Budget Deficits." Federal Reserve Bank of St. Louis Economic Synopses, No. 26, November 2003; https://research.stlouisfed.org/publications/es/03/ES0326.pdf.

Neely, Christopher J. and Rapach, David E. "International Comovements in Inflation Rates and Country Characteristics." Journal of International Money and Finance, November 2011, 7(30), pp. 1471-90.

Newey, Whitney K. and West, Kenneth D. "A Simple, Positive Semi-Definite, Heteroskedasticity and Autocorrelation Consistent Covariance Matrix." Econometrica, May 1987, 55(3), pp. 703-08.

Otrok, Christopher and Whiteman, Charles H. "Bayesian Leading Indicators: Measuring and Predicting Economic Conditions in lowa." International Economic Review, November 1998, 39(4), pp. 997-14.

Roubini, Nouriel and Sachs, Jeffrey D. "Political and Economic Determinants of Budget Deficits in the Industrial Democracies." European Economic Review, May 1989, 33(5), pp. 903-33.

Sargent, Thomas J. and Sims, Christopher A. "Business Cycle Modeling Without Pretending to Have Too Much a Priori Economic Theory," in Christopher A. Sims, ed., New Methods in Business Cycle Research: Proceedings from a Conference. Minneapolis, MN: Federal Reserve Bank of Minneapolis, October 1977, pp. 45-109.

Stock, James H. and Watson, Mark W. "New Indexes of Coincident and Leading Economic Indicators," in Olivier J. Blanchard and Stanley Fischer, eds., NBER Macroeconomics Annual 1989. Cambridge, MA: MIT Press, 1989, pp. 351-94.

Stock, James H. and Watson, Mark W. "A Procedure for Predicting Recessions with Leading Indicators: Econometric Issues and Recent Experience," in James H. Stock and Mark W. Watson, eds., Business Cycles, Indicators, and Forecasting. Chicago: University of Chicago Press, 1993, pp. 95-153.

Stock, James H. and Watson, Mark W. "Forecasting Using Principal Components from a Large Number of Predictors." Journal of the American Statistical Association, December 2002, 97(460), pp. 1167-79.

Strawczynski, Michael and Zeira, Joseph. "Cyclicality of Fiscal Policy: Permanent and Transitory Shocks." CEPR Discussion Paper No. DP7271, Centre for Economic Policy Research, April 2009.

Vale, Bent. "The Norwegian Banking Crisis," in Thorvald G. Moe, Jon A. Solheim, and Bent Vale, eds., The Norwegian Banking Crisis. Norges Bank Occasional Papers No. 33, May 2004, pp. 1-20;

http://www.norges-bank.no/upload/import/publikasjoner/skriftserie/33/hele_heftet.pdf. 